\title{
Estimation of Peak Flood Discharge for an Ungauged River: A Case Study of the Kunur River, West Bengal
}

\author{
Suvendu Roy ${ }^{1}$ and Biswaranjan Mistri ${ }^{2}$ \\ ${ }^{1}$ University of Kalyani, Nadia, West Bengal 741235, India \\ ${ }^{2}$ The University of Burdwan, Burdwan, West Bengal 713101, India \\ Correspondence should be addressed to Suvendu Roy; suvenduroy7@gmail.com
}

Received 10 September 2013; Revised 21 October 2013; Accepted 29 October 2013

Academic Editor: Achim A. Beylich

Copyright (c) 2013 S. Roy and B. Mistri. This is an open access article distributed under the Creative Commons Attribution License, which permits unrestricted use, distribution, and reproduction in any medium, provided the original work is properly cited.

\begin{abstract}
Due to unavailability of sufficient discharge data for many rivers, hydrologists have used indirect methods for deriving flood discharge amount, that is, application of channel geometry and hydrological models, for the estimation of peak discharge in the selected ungauged river basin(s) in their research/project works. This paper has studied the estimation of peak flood discharge of the Kunur River Basin, a major tributary of the Ajay River in the lower Gangetic plain. To achieve this objective, field measurements, GIS technique, and several channel geometry equations are adopted. Three important geomorphic based hydrological modelsmanning's equation, kinematic wave parameter (KWP), and SCS curve number (CN) method-have been used for computing peak discharge during the flood season, based on daily rainfall data of September, 2000. Peak discharges, calculated by different given models, are $239.44 \mathrm{~m}^{3} / \mathrm{s}, 204.08 \mathrm{~m}^{3} / \mathrm{s}$, and $146.52 \mathrm{~m}^{3} / \mathrm{s}$, respectively. The hydrograph has demonstrated the sudden increase with heavy rainfall from the 18 th to the 22 nd of September, 2000. As a result, a havoc flood condition was generated in the confluence zone of Ajay and Kunur Rivers. This hydrograph might be not only successful application for flood forecasting but also for management of the lower Ajay River Basin as well as the downstream area of Kunur Basin.
\end{abstract}

\section{Introduction}

In India most of the watersheds up to $500 \mathrm{~km}^{2}$ geographical area can be categorized as ungauged catchments [1]. Majority of river basins are either sparsely gauged or not gauged at all, where the lack of hydrological and catchment information makes obstruction for watershed planning [2]. As per Sing et al. [1], hydrological response from each catchment assists in flood routing vis-à-vis in flood modeling and flood forecasting. Schumm [3] apprises that water and sediment discharge are the principal determinants of the dimensions of a river channel (width, depth, meander wavelength, and gradient). Physical characteristics of river channels, such as width/depth ratio, sinuosity, and pattern (braided, meandering, and straight) are significantly affected by the flow rate and sediment discharge. According to Bhatt and Tiwari [2], channel geometry method is an alternative mode of estimating flood discharge for regional flood frequency analysis. River bed characteristics-channel width, cross-section area, river bed gradient, and bank side slope-are crucial parameters for alternative techniques of discharge estimation.
In hydrology, the term "peak discharge" stands for the highest concentration of runoff from the basin area. The concentrated flow of the basin greatly exaggerated and overtops the natural or artificial bank and this might be called flood [4]. In this paper, local enquiries have played an important role to know actual depths of river water during the major floods. On the contrary, the accurate estimation of flood discharge remains one of the major challenges to many engineers and planners, who are involved in project design. Hence, hydrological data and information are limited [2]. In this case, geomorphic parameters have availed to discharge estimation. Geomorphic parameters such as, channel-pattern, meander wavelengths, and palaeochannels dimensions, were firstly used in palaeohydrology by Dury $[5,6]$ and Schumm [3] and were modified subsequently depending upon the area of application [7-11]. In the USA, the relationship between flood discharge and river channel dimensions was initially developed after following the suggestion of Langbein's [12] research in Nevada. After achievement of studies, including Hedman et al. [13, 14], Scott and Kunkler [15], Riggs [16], Osterkamp 
and Hedman [17], Webber and Roberts [18], Omang et al. [19], Wahl [20, 21], and Lawlor [22], the method was accepted by the water resource division of the US Geological Survey as an operational technique. In the central USA, Williams [23] established relationships between bankfull discharge and channel dimensions with sample data of 36 gauging stations. In Indian context, several researchers [2, 24, 25] have applied indirect methodologies for estimation of discharge of several ungauged catchments.

Flood is a natural phenomenon in the West Bengal. The state with a geographical area of $88752 \mathrm{~km}^{2}$ occupies $2.7 \%$ of India's land and supports $8.02 \%$ (census, 2011) of total Indian population. The flood prone area of West Bengal is $37,660 \mathrm{~km}^{2} ; 42.43 \%$ of total geographical area is more elevated than the average of $12.17 \%$ [26]. The downstream areas of 26 river basins are frequently flood affected in the rainy season in all over the West Bengal. Enormouse flood has occurred in this region from the end of September till the mid of October [27]. The problem of flood is more difficult to control in this state because of two major aspects: (i) the very small longitudinal gradient in general and (ii) the funnel-shaped basin (e.g., Damodar, Ajay, Dwarakeswar, and Kasai River Basins) with a wide upper catchment and a narrow lower catchment. Under these circumstances, the basins generally have phenomenal increase of peak discharge $[28,29]$. With this vulnerability of West Bengal, there is no availability of sufficient hydrological data to predict the nature of flooding behavior of river. Correspondingly, Kunur is also a notable river, which causes flood in the Mangalkote and its adjoining Blocks of Barddhaman District [30].

1.1. Purpose of This Research. The major purpose of this study is to estimate the peak discharge of the ungauged Kunur River Basin during heavy flood, using indirect methods with channel geometry. There are used numerical models instead of modern instrument based velocity measurement (current meters) due to lack of departmental instrument, finance, and during flood, the whole confluence zone is inundated completely and there is no scope to reach to the outlet of the Kunur River to measure the discharge. In lean season, there was no flow for both rivers (Ajay and Kunur) and havoc flood condition is a sudden scenario (mainly in September) for accumulation of huge monsoonal runoff from upstream area of these two basins. On the basis of water input-output graph of the Kunur River Basin [31], it has been observed that flood comes during September (Figure 1). Nevertheless, Mitra [31] did not estimate the monthly discharge data of Kunur River during floods; this work has been an attempt to estimate it. This study also attends to understand regional hydrology for study area, which provides a concept to design surface water and flood management project.

\section{Materials and Method}

2.1. Study Area. The Kunur River Basin, which covers a geographical area of $922.40 \mathrm{~km}^{2}$, is the second largest draining inland basin of north-east ward of Barddhaman District and a major right bank tributary of the Ajay River. Geographically,

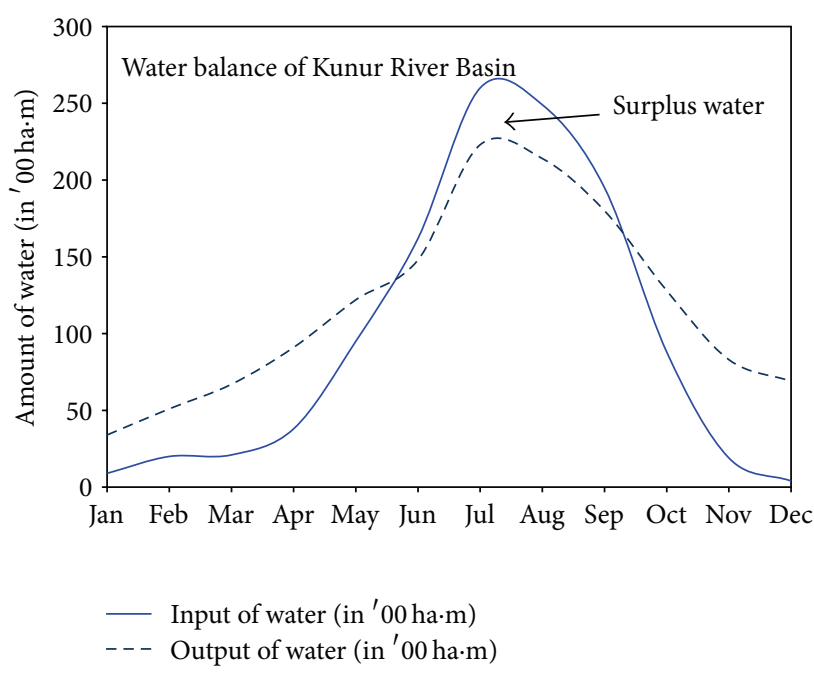

FIGURE 1: Input-output situation of the Kunur River Basin (source: [31]).

it is located between $23^{\circ} 25^{\prime} \mathrm{N}$ to $23^{\circ} 40^{\prime} \mathrm{N}$ latitude and $87^{\circ} 15^{\prime} \mathrm{E}$ to $87^{\circ} 55^{\prime} \mathrm{E}$ longitude and administratively divided into several police stations-Faridpur, Durgapur, Kanksa, Ausgram, Budbud, Mangalkote, and Bhatar-in the north-central part of Barddhaman. The outlet of this watershed is near to the village "Kogram," about $38 \mathrm{~km}$ from Burdwan Town on the Burdwan-Katwa road (Figure 2). The Kunur River represents a basin of 5th order with a drainage density that is equal to $0.85 \mathrm{~km} / \mathrm{km}^{2}$ and the drainage pattern is more or less dendritic with elongated shape [32]. As per Mitra [31], the upstream and central part of the Basin has a forest cover interspersed with paddy fields along watercourses, $13.80 \%$ of the basin area is under forest while $53.90 \%$ is cultivated. $26.20 \%$ of the Basin area is not available for the cultivation and $6.10 \%$ is culturable waste.

Geographically this basin is tropical; the Tropic of Cancer $\left(23^{\circ} 30^{\prime} \mathrm{E}\right)$ is passing over the basin from West to East. The sea coast is located at least $220 \mathrm{~km}$ away from the Bay of Bengal, and somewhat extreme tropical climate is experienced here [34]. The average annual rainfall is $1400 \mathrm{~mm}$ of which the maximum occurs within the second week of June to September.

During summer months, rainfall nearly exceeds $100 \mathrm{~mm}$ and it is even over $1500 \mathrm{~mm}$ during rainy months [32]. Geohydrologically, the total basin is divided into three types of geohydrological characteristics. First, the upper catchment of the Kunur River Basin is covered by hard rock, mainly Archaean formation with high grade metamorphic rocks of granite gneiss, commonly referred as "Bengal Gneiss." Furthermore, middle portion consists of semiconsolidated formation of the Gondwana Sedimentaries and hard lateritic patches. Finally, the lower catchment area is mainly un-consolidated with new alluvial of the Ajay and Kunur floodplains [35]. As a result, maximum rainfalls in the upper and middle catchment area are turned into overland flow due to low infiltration capacity and make huge water pressure in the downstream channel of the Kunur River. To generate floods in the lower Ajay River 


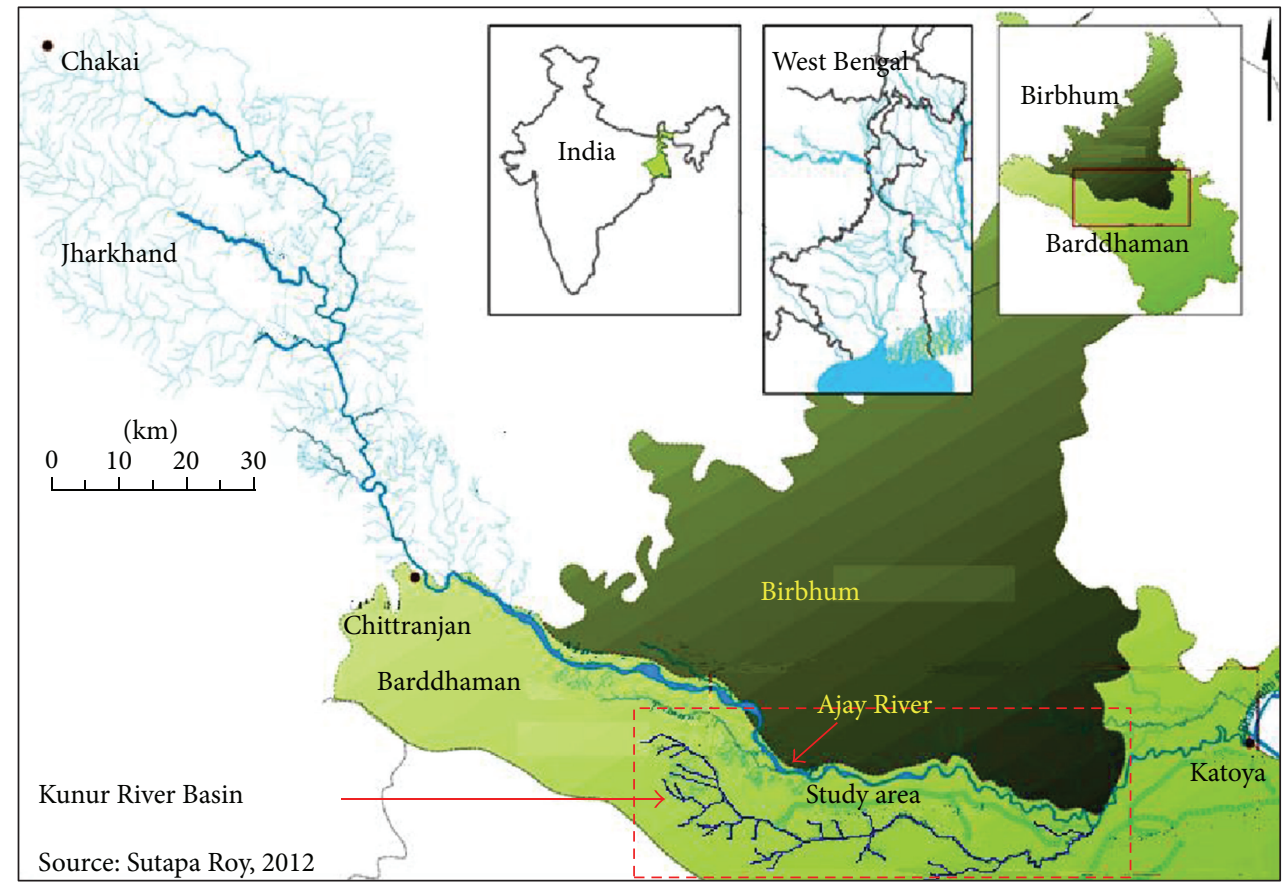

(a)

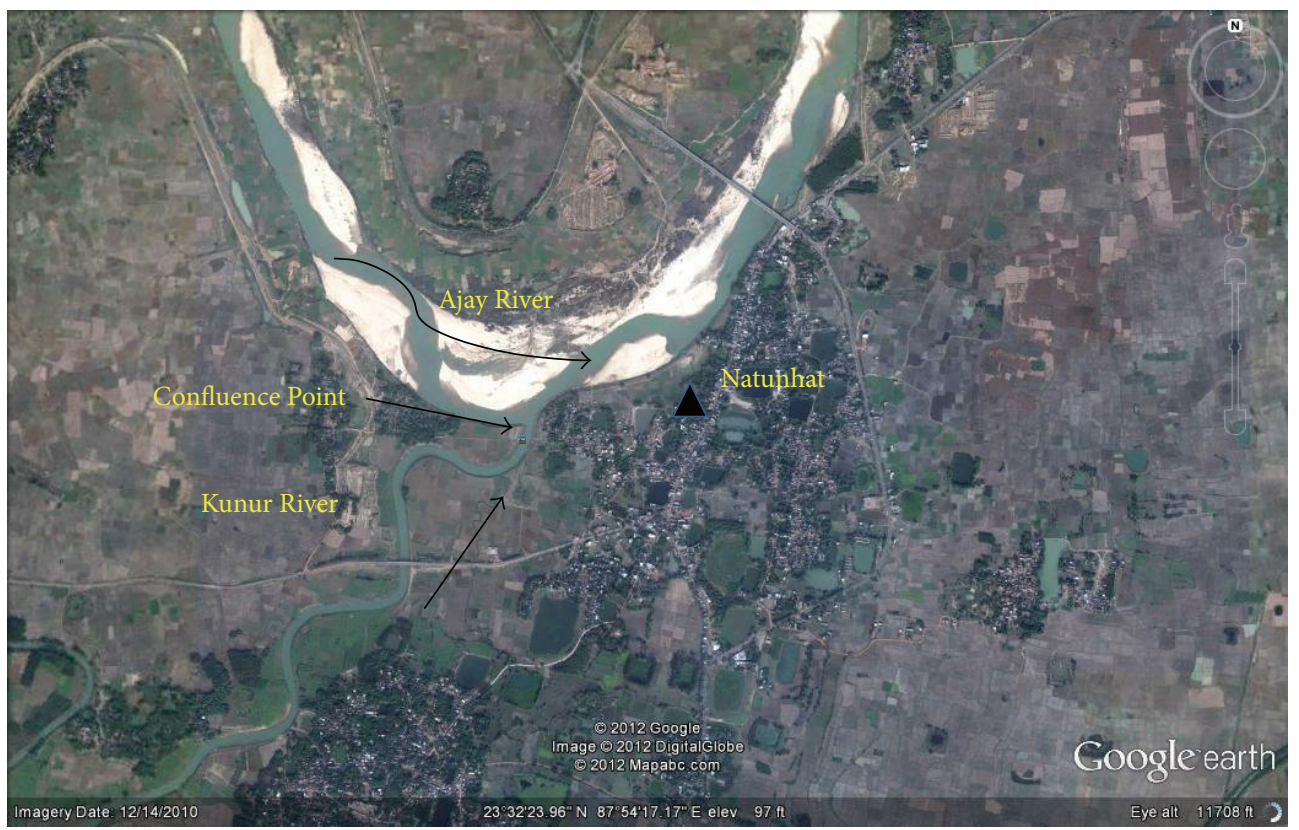

(b)

FIgURE 2: Location map of the study area.

Basin, discharge of the Kunur River Basin has played very important role to make a devastative form of these floods. Kunur River is an important tributary of the Ajay River and $33 \%$ area of lower Ajay River Basin (Area of Lower Ajay River Basin is $2816.25 \mathrm{~km}^{2}$ and $79.65 \%$ areas are flood affected entirely or partially [32].) is covered by this basin. Mukhopadhyay [32] stated that the lower Ajay River Basin has been suffering from floods since time immemorial. The major recorded flood years are 1956, 1959, 1970, 1971, 1973, 1978, $1984,1995,1999,2000,2005$, and 2007. Unfortunately, there is no availability of hydrological data, apart from rainfall data of the Kunur Basin. Even though, there is no gauging station on the Kunur so that there is a lack of discharge data [31]. Figures 3(a) and 3(b) have given a clear idea about spatial pattern of floods in the lower Ajay River Basin and vulnerability of the Kunur River Basin. There are several causes behind 


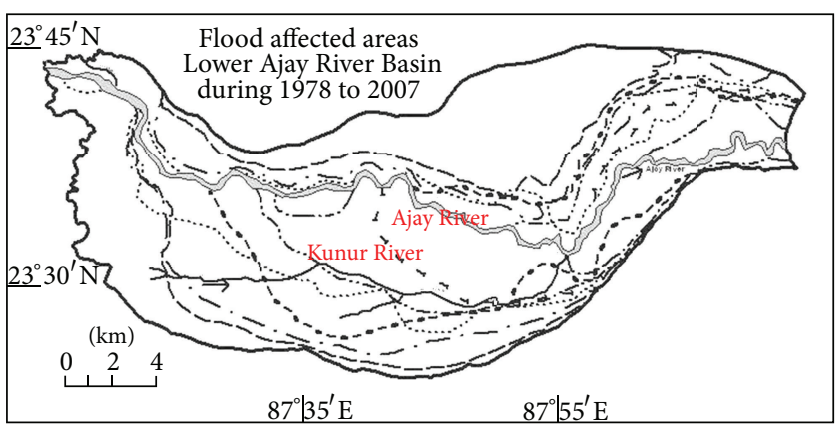

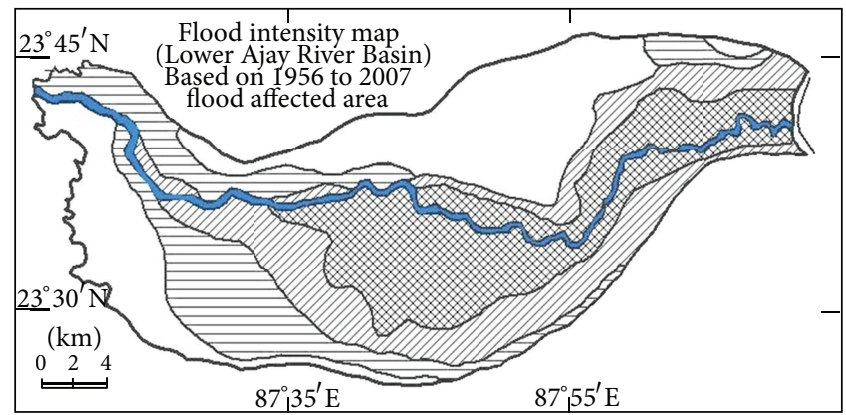

Highly affected area $(>60 \%)$

Moderately affected area (40-60\%)

Least affected area $(<40 \%)$

(a)

(b)

FIgURE 3: Spatial pattern of floods in the lower Ajay River Basin (source: [32]).

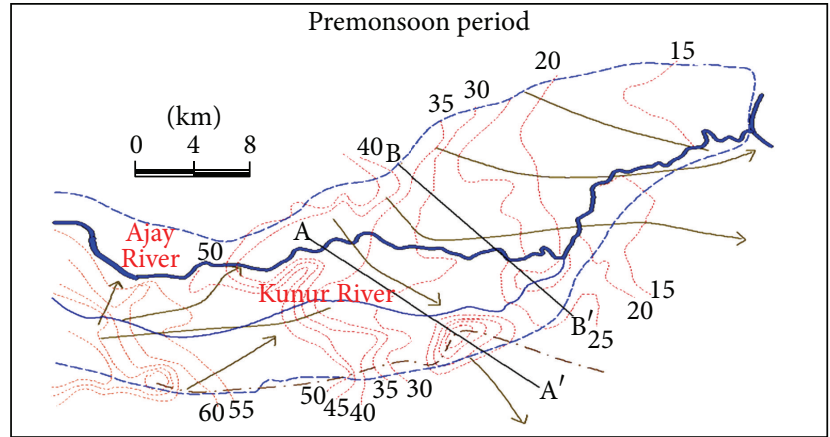

- - - Basin boundary

Ground water contour $(\mathrm{m})$
_. Direction of ground water flow

(a)
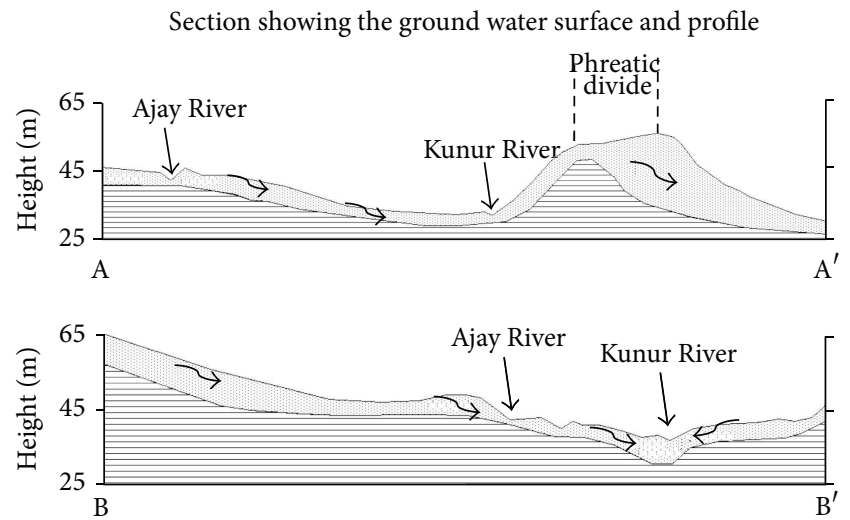

(b)

Figure 4: Subsurface water flow in the confluence zone of the Ajay and Kunur Rivers (source: [35]).

generating havoc flood in the downstream area of the Kunur River: (i) gradual decreasing channel width of Kunur river towards the confluence point [30], (ii) huge sedimentation in the confluence zone disturbed the longitudinal profile/slope of the Kunur river [30], (iii) effluent condition of Kunur River and very good ground water potentiality $\left(150 \mathrm{~m}^{3} / \mathrm{hr}\right)$ [35] (Figures 4(a) and 4(b)), (iv) high percentage of cumulative thickness of granular materials $(86.50 \% ; 160.0$ meters within 185.0 metres bore hole), and high storage coefficient $(5.2 \times$ $10^{-4}$ ) [35], and (v) topographically depression in the right bank of the Ajay river [30]. All these cause pace overland flow of the Kunur Basin and high amount of discharge. As per Sing et al. [1], knowledge of peak discharge is essential for safe and economical planning and design of hydraulic structures. Therefore, to provide sustainable management of flood prone area in the lower Ajay River Basin, estimation of discharge data of the Kunur River is extremely required.

2.2. Method. The entire research work has carried out with four steps, that is, literature survey, field measurement, graphical representation, and discharge estimation using hydrological models and their quantitative analysis. Several journals, books, reports, and thesis have been reviewed carefully and different hydrological models have been chosen from there. Among them, three important models have been selected for the estimation of peak discharge of the Kunur River Basin. All three models have been used for their geomorphic perspective with GIS based calculation. In the first model, manning equation is applied for discharge estimation which works with in-stream channel geometry and texture of river bed. In the Second model, used model is Kinematic Wave Parameter (KWP) model is used, in which rainfall intensity, an important parameter for runoff generation of basin area, has been taken into consideration for discharge estimation. Monsoonal rainfall amount is the basic input for generating peak discharge and therefore rainfall data for the entire month September (30 days) of the year 2000 was used here. Year 2000 was a havoc flood year in the flood history of West Bengal. Lastly, SCS curve number method has been used for deals with land use character and soil hydrology, which 
TABLE 1: Calculation of hydraulic radius $\left(R_{h}\right)$ of the study reach.

\begin{tabular}{|c|c|c|c|c|c|c|c|c|c|}
\hline Site & $\begin{array}{c}\text { Cross-section } \\
\text { line }\end{array}$ & $B$ & $b$ & $y$ & $l$ & $z y$ & $A$ & $P$ & $R_{h}$ \\
\hline At outlet of Kunur River & $A B$ & $56.3 \mathrm{~m}$ & $34.4 \mathrm{~m}$ & $6 \mathrm{~m}$ & $14.4 \mathrm{~m}$ & $21.9 \mathrm{~m}$ & $272.1 \mathrm{~m}^{2}$ & $63.2 \mathrm{~m}$ & $4.31 \mathrm{~m}$ \\
\hline
\end{tabular}

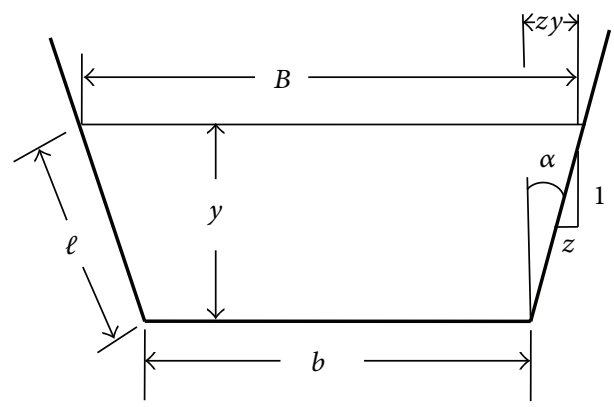

FIgURE 5: Trapezoidal open channel cross-section (source: [41]).

are the important factors for making variation of runoff generation. Here, used rainfall data has been computed by River Research Institute, Kolkata, at the Illambazar gauge station, which is situated in the outside of Kunur Basin. But, the distance is only five kilometres from the northern edge of this basin (middle part) (Figure 7).

2.2.1. Manning Equation and Peak Discharge. As per Chow [33], Barnes Jr. [36], Benson and Dalrymple [37], Limerinos [38], Jarrett [39], and Summerfield [40] in case of limited field measurements and data availability for any river, Manning's method is considered to be an accurate and reliable method for river discharge estimation. Hydraulic Radius is an important parameter in the manning equation. It is varying with the cross-sectional shapes (rectangular, circular, semicircular, trapezoidal, and triangular) of open channel. For calculating it also needs to use different mathematical equations or Pythagoras' theorem. In the present study, channel of the Kunur River looks like a trapezoidal shape (Figure 6(a), Table 1). A trapezoidal open channel cross-section is shown in Figure 5 along with the parameters used to specify its size and shape. Those parameters are $b$, the bottom width; $B$, the width of the liquid surface; $l$, the wetted length measured along the sloped side; $y$, the liquid depth; and $\alpha$, the angle of the sloped side from the vertical.

The hydraulic radius for the trapezoidal cross-section is often expressed in terms of liquid depth, bottom width, and side slope $(y, b$, and $z)$ as follows. The cross-sectional area $(A)$ of flow $=$ the area of the trapezoid $=$

$$
A=\frac{y(b+B)}{2}=\left(\frac{y}{2}\right)(b+B) .
$$

The wetted perimeter for trapezoidal cross-section is $P=b+$ $2 l$.

Now, hydraulic radius of a trapezoidal cross-section is calculated by the following equation: $R_{h}=A / P$.

The velocity of stream flow is influenced by the gradient, roughness, and cross-section form of a channel [42]. The manning equation is a more widely applied estimator which incorporates an index of channel bed roughness [40]. The Manning equation $(v)$ defines the mean flow velocity $(v)$ as

$$
v=\frac{k\left(R_{h}^{2 / 3} \times s^{1 / 2}\right)}{n}
$$

where $k$ is a dimensionless constant ( $=1$ in metric units and 1.46 in English units), $R_{h}$ is the hydraulic radius (defined as the cross-section area divided by the wetted perimeter, but commonly approximated by mean channel depth), $s$ is the longitudinal slope of channel, and $n$ is the Manning roughness coefficient, another dimensionless number that defines the flow resistance of a unit of bed surface $[43,44]$. This Manning roughness coefficient $(n)$ is usually estimated from table values as given by Chow [33] or by comparison with photographs illustrating channels of known roughness [45] (Figure 6(b)). The assignment of roughness coefficients calculation in natural channels has been performed by different researchers [36, 46] comparing cross-sectional area, sand river profiles with photographs of typical river, and creek cross-sections or by means of empirical equations [47, 48]. As per Chow [33] the value range of Manning roughness coefficient $(n)$ for the large channel (width $>30 \mathrm{~m}$ ) with regular channel lacking boulders or vegetation is from 0.025 to 0.060 . Alternatively, as per Simons and Richardson [45], if bedform is characterized with dunes it will be in the range of $0.018-0.035$. In this river, the channel of both types of characteristics has been observed and therefore Manning roughness coefficient (n) was taken as 0.035 for applying in Manning equation.

\subsubsection{Kinematic Wave Parameter (KWP) for Flow Velocity and} Discharge Estimation. Runoff concentration for any river basin is dependent upon two interrelated systems, that is, the channel network and the hill slopes. The hill slopes control the production of storm water runoff which is treated as peak discharge when it reached at the basin outlet [49]. With considering these two systems Rodriguez-Iturbe et al. [50] had presented a kinematics wave relation for the estimation of flow velocity with using the flowing equation:

$$
V_{\Omega}=0.665 \alpha_{\Omega}^{0.6}\left(i_{r} A\right)^{0.4}, \quad \alpha_{\Omega}=\frac{S_{\Omega}^{0.5}}{n B^{2 / 3}},
$$

where $V_{\Omega}$ is flow velocity $(\mathrm{m} / \mathrm{s}), i_{r}$ is rain intensity $(\mathrm{cm} / \mathrm{h}), A$ is drainage basin area $\left(\mathrm{km}^{2}\right), S_{\Omega}$ is slope of main river in drainage basin outlet (\%), $n$ is Manning's roughness coefficient, and $B$ is mean flow width in outlet of drainage basin (m).

2.2.3. Effective Discharge Estimation. To estimate the effective discharge of any watershed, Rodriguez-Iturbe et al. [50] had used geomorphologic model and relations for preparing this equation:

$$
Q_{e}=i_{r} * A
$$




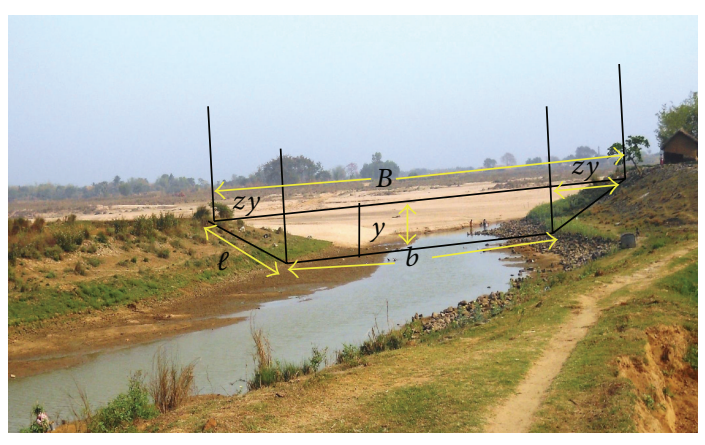

(a)

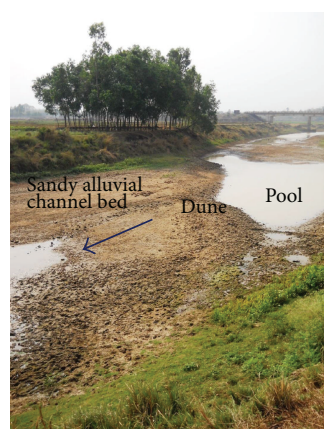

(b)

Figure 6: (a) Trapezoidal channel cross-section of the Kunur River; (b) bed-form characteristic with dunes and pool.

where $Q_{e}$ is effective discharge, $i_{r}$ is rainfall intensity $(\mathrm{cm} / \mathrm{h})$, and $A$ is area of total basin. It is treated as the equilibrium discharge for any basin. Therefore, this equation is used here to quantify basic discharge capacity of Kunur River and to make a comparative analysis with the other three models to quantify their level of efficiency.

\subsubsection{SCS Curve Number Method for Direct Runoff Estima-} tion. The SCS curve number method is a simple, widely used, and efficient method for determining the approximate amount of runoff depth from a rainfall event in a particular area. For drainage basins, where no runoff has been measured, the curve number method can be used to estimate the depth of direct runoff from a measured rainfall amount over the study area. The SCS Curve Number Method was originally developed by the Soil Conservation Service $[51,52]$ for the management of water resource in the United States for agricultural development [33]. In this method, the following equation is used to calculate the direct runoff from any ungauged basin:

$$
Q=\frac{(P-0.2 S)^{2}}{(P+0.8 S)}
$$

where $Q$ is estimated direct runoff $(\mathrm{mm}), P$ is maximum storm rainfall within a day $(\mathrm{mm})$, and $S$ is the potential maximum retention. $S$ can be calculated from $\mathrm{CN}$ value by this equation; that is, $S=(25400 / \mathrm{CN})-254$ and $\mathrm{CN}$ value can be extracted from the table (see [33, Table 5.2.2, pp. 150]) value with weight index value (Table 4). After calculating the direct runoff or excess runoff from any basin $(Q)$, to estimate the peak runoff rate $\left(\mathrm{m}^{3} / \mathrm{s}\right)$, the following equation should be used [33]:

$$
q_{p}=0.208 *\left(\frac{A * Q}{T_{p}}\right)
$$

where $A$ is area of drainage basin $\left(\mathrm{km}^{2}\right), Q$ is excess rainfall $(\mathrm{mm}), q_{p}$ is peak runoff rate unit hydrograph $\left(\mathrm{m}^{3} / \mathrm{s}\right)$, and $T_{p}$ is time to peak runoff unit hydrograph (h). In that equation, the only unknown parameter is time to peak $\left(T_{p}\right)$. This can be estimated in terms of time of concentration $\left(T_{c}\right)$. Relation between $T_{p}$ and $T_{c}$ is shown in this equation:

$$
T_{p}=0.7 T_{c} .
$$

To compute $T_{c}$ value, Kirpich [53] developed this empirical equation:

$$
T_{c}=0.02 L^{0.77} S^{-0.385},
$$

where $T_{c}$ is time of concentration ( $\mathrm{min}$ ), $L$ is maximum length of travel (m), and $S$ is slope, that is equal to $H / L$, where $H$ is the difference in elevation between the most remote point in the basin and the outlet. The parameters to estimate the time of concentration can be derived from the topographic maps. So, after estimating $T_{c}$, we can easily calculate $T_{p}$, and consequently the peak runoff rate $\left(q_{p}\right)$.

2.2.5. Models Calibration. To determine the level efficiency of predicted discharge data by indirect methods, it is very important to compare them with observed discharged data of the same river. But due to lack of observed discharged data of Kunur River, all three predicted discharged data have been compared with the estimated effective discharge which is taken as equilibrium discharged volume of the Kunur Basin using the following methods.

Relative Mean Error (RME). Relative mean error relation could be used to determine the deviation between calculated peak discharge and observed peak discharge, and the following equation is used for that

$$
\mathrm{RME}=\frac{1}{n} \sum \mathrm{RE}_{i}, \quad \mathrm{RE}_{i}=\frac{\left[\left(\mathrm{Q}_{\mathrm{op}}-\mathrm{Q}_{\mathrm{cp}}\right) * 100\right]}{Q_{\mathrm{op}}},
$$

where $\mathrm{RE}_{i}$ is relative error percent for each of events, $Q_{\mathrm{op}}$ is observed peak discharge, and $Q_{c p}$ is calculated peak discharge.

Root of Mean Square Error (RMSE). Root of mean square error relevant to peak discharge is presented by

$$
\mathrm{RMSE}=\left[\frac{1}{n}\left(\sum \mathrm{SE}_{i}\right)\right]^{1 / 2}, \quad \mathrm{SE}_{i}=\left(Q_{\mathrm{op}}-Q_{\mathrm{cp}}\right)^{2},
$$


TABLE 2: Estimation of bankfull discharge during flood of the Kunur River at the outlet using manning equation.

\begin{tabular}{|c|c|c|c|c|c|c|c|}
\hline Site & $\begin{array}{l}\text { Cross-section } \\
\text { line }\end{array}$ & $\begin{array}{l}\text { Hydraulic } \\
\text { radius } R(\mathrm{~m})\end{array}$ & $\begin{array}{c}\text { Slope-m/m } \\
(S)\end{array}$ & $\begin{array}{c}\text { Manning } \\
\text { roughness } \\
\text { coefficient }(n)\end{array}$ & $\begin{array}{c}\text { Manning } \\
\text { equation }(v \mathrm{~m} / \mathrm{s})\end{array}$ & $\begin{array}{l}\text { Cross-section area } \\
(\mathrm{CSA})=w \cdot d\left(\mathrm{~m}^{2}\right)\end{array}$ & $\begin{array}{c}\text { Discharge } \\
(Q=w \cdot d \cdot v) \\
\mathrm{m}^{3} / \mathrm{s}\end{array}$ \\
\hline $\begin{array}{l}\text { At outlet of } \\
\text { Kunur River }\end{array}$ & $A B$ & 4.31 & 0.01 & 0.035 & 0.88 & 272.1 & 239.44 \\
\hline
\end{tabular}

TABLE 3: The required parameters for measurement flow velocity from kinematic wave parameter and discharge.

\begin{tabular}{|c|c|c|c|c|c|c|c|}
\hline $\begin{array}{l}\text { Rain intensity } \\
(\mathrm{cm} / \mathrm{h}) \\
\left(i_{r}\right)\end{array}$ & $\begin{array}{l}\text { Drainage basin } \\
\text { area }\left(\mathrm{km}^{2}\right) \\
(A)\end{array}$ & $\begin{array}{c}\text { Slope of main } \\
\text { river in drainage } \\
\text { basin outlet (\%) } \\
\left(S_{\Omega}\right)\end{array}$ & $\begin{array}{l}\text { Manning's } \\
\text { roughness } \\
\text { coefficient }(n)\end{array}$ & $\begin{array}{l}\text { Mean flow } \\
\text { width in outlet } \\
\text { of drainage } \\
\text { basin }(\mathrm{m})(B)\end{array}$ & $\begin{array}{c}\text { Flow velocity }(\mathrm{m} / \mathrm{s}) \\
\left(V_{\Omega}\right) \\
\begin{array}{c}V_{\Omega}=0.665 \alpha_{\Omega}^{0.6}\left(i_{r} A\right)^{0.4} \\
\alpha_{\Omega}=S_{\Omega}^{0.5} / n B^{2 / 3}\end{array}\end{array}$ & $\begin{array}{l}\text { Cross-section } \\
\text { area }(\mathrm{CSA})= \\
w \cdot d\left(\mathrm{~m}^{2}\right)\end{array}$ & $\begin{array}{c}\text { Discharge } \\
(Q=w \cdot d \cdot v) \\
\mathrm{m}^{3} / \mathrm{s}\end{array}$ \\
\hline $0<4$ & 922.40 & 0.19 & 0.035 & 56.3 & 0.75 & 272.10 & 204.08 \\
\hline
\end{tabular}

TABLE 4: Compute the weighted curve number (CN) using table value (see Table 5.5.2, p.150 in [33]).

\begin{tabular}{|c|c|c|c|c|}
\hline $\begin{array}{l}\text { Hydrological soil } \\
\text { group }\end{array}$ & Major land use and soil characteristics & $\begin{array}{l}\text { Covering basin } \\
\text { area }(\%)\end{array}$ & $\mathrm{CN}$ & Product \\
\hline $\mathrm{A}$ & Urban area with 50 to $75 \%$ impervious land & 3 & 49 & 147 \\
\hline B & $\begin{array}{l}\text { Moderate infiltration rate with coarse } \\
\text { texture land, pasture, and open scrap area }\end{array}$ & 7 & 79 & 553 \\
\hline $\mathrm{C}$ & $\begin{array}{l}\text { Low infiltration rate with fine sandy loam, } \\
\text { dense forest, and degraded wood land }\end{array}$ & 55 & 77 & 4235 \\
\hline \multirow[t]{2}{*}{$\mathrm{D}$} & Fine clay to silt soil with agricultural land & 35 & 72 & 2520 \\
\hline & hted $\mathrm{CN}=7455 / 100=74.55$ & $\Sigma 100$ & & $\Sigma 7455$ \\
\hline
\end{tabular}

where $\mathrm{SE}_{i}$ is relative error for each of events, $Q_{\mathrm{op}}$ is Observed peak discharge, and $Q_{c p}$ is calculated peak discharge.

The field surveys were conducted along river course from confluence towards upstream; six river cross-sections were surveyed to measure different parameters of channel geometry. The region has sparse elevations, which have been surveyed using GPS (Garmin eTrex 30). The river cross-sections were surveyed using Autolevel (Sokkia $\mathrm{C}_{10}$ ) with $2.5 \mathrm{~mm}$ standard deviation for one $\mathrm{km}$ double run leveling, and 100 metres tape, and 4 metres staff are also used for these surveys. The longitudinal slope and hydraulic radius have been calculated to determine flow velocity using manning's equation and ASTER data has been also used to get slope factor using Global Mapper v14.0 software.

\section{Result and Discussion}

3.1. Calculation of Peak Bankfull Discharge Using Manning Equation. To begin this study, hydraulic radius has been calculated based on model for a trapezoidal cross-section. Table 1 indicates that hydraulic radius of Kunur outlet section is 4.31 metres. Then, Manning's equation has been applied to calculate the mean maximum bank discharge of the Kunur River at its mouth (Figure 2; Table 2). Finally, this manning equation based hydrological equation has estimated that maximum bank capacity of the Kunur River is $239.44 \mathrm{~m}^{3} / \mathrm{s}$, which might be the peak discharge volume of this river.

3.2. Kinematic Wave Parameter (KWP) for Flow Velocity and Discharge Estimation. After applying kinematic wave parameter equation on the Kunur River, the result is more likely similar to the previous estimation. Mean flow velocity of Kunur River at the outlet is $0.75 \mathrm{~m} / \mathrm{s}$ and computed discharge is $204.08 \mathrm{~m}^{3} / \mathrm{s}$ (Table 3). Effective discharge of Kunur River Basin is $179.35 \mathrm{~m}^{3} / \mathrm{s}$, which is the mean equilibrium discharge for this basin that is used here as observed discharge to calculate the model wise efficiency.

3.3. SCS Curve Number Method and Peak Discharge. Based on the hydrological soil group, the maximum area of Kunur watershed was observed to be under hydrological soil group C (55\%) and followed by $35 \%$ of D, $7 \%$ of B, and $3 \%$ of group A. Similarly, the study area was identified into five major land use classes namely, agricultural land, dense to degraded Sal forest, wasteland, settlement, and hard surface. The major portion of this watershed is under agricultural land. Curve number table of the Soil Conservation Service was used to determine the curve number of the watershed. By intersecting the land use map and soil map the curve number was assigned to the each combination of land use and soil type. Weighted value of $\mathrm{CN}$ was found out to be 74.55 for AMC II conditions. The daily rainfall data for entire month September in the year 2000 was collected and the weighted curve number of the watershed has been used for the estimation of directs runoff. The calculated direct runoff was found out to be $88.73 \mathrm{~mm}$ for monsoon season (19th September, highest one day rainfall, $160 \mathrm{~mm}$ ) of the year 2000 which is approximately 17.30 percent of the total rainfall in the entire month September and $55.46 \%$ of that day (Table 8 ).

Now, the potential maximum retention $(S)$ can be easily calculated from the $\mathrm{CN}$ value, $S=(25400 / \mathrm{CN})-254$. Therefore, $S=86.71$ and $Q$ or accumulated runoff depth 
TABLE 5: Calculation of peak runoff using SCS curve number method.

\begin{tabular}{|c|c|c|c|c|c|c|}
\hline $\begin{array}{l}\text { Potential } \\
\text { maximum } \\
\text { retention }(S)\end{array}$ & $\begin{array}{c}\text { Maximum one } \\
\text { day rainfall } \\
\text { during strom } \\
(P)\end{array}$ & $\begin{array}{l}\text { Direct runoff } \\
\text { or excess } \\
\text { runoff }(Q)\end{array}$ & $\begin{array}{c}\text { Area of the } \\
\text { total basin }(A)\end{array}$ & $\begin{array}{c}\text { Time of } \\
\text { concentration } \\
(\min )\left(T_{c}\right)\end{array}$ & $\begin{array}{l}\text { Time to peak runoff } \\
\text { unit hydrograph }(\mathrm{h}) \\
\qquad\left(T_{p}\right)\end{array}$ & $\begin{array}{l}\text { Peak runoff rate } \\
\text { unit hydrograph } \\
\left(\mathrm{m}^{3} / \mathrm{s}\right)\left(q_{p}\right)\end{array}$ \\
\hline $86.71 \mathrm{~mm}$ & $160 \mathrm{~mm}$ & $88.73 \mathrm{~mm}$ & $922.40 \mathrm{~km}^{2}$ & 165.98 & 116.18 & 146.52 \\
\hline
\end{tabular}

TABLE 6: Calculated peak discharge $\left(\mathrm{m}^{3} / \mathrm{s}\right)$ from three models in Kunur River Basin.

\begin{tabular}{|c|c|c|c|c|}
\hline Event time* & $\begin{array}{c}\text { Effective discharge or } \\
\text { observed discharged } \\
\text { data }\left(\mathrm{m}^{3} / \mathrm{s}\right)\end{array}$ & $\begin{array}{c}\text { Estimated by } \\
\text { manning equation } \\
\text { model }\left(\mathrm{m}^{3} / \mathrm{s}\right)\end{array}$ & $\begin{array}{c}\text { Estimated by } \\
\text { kinematic wave } \\
\text { parameter }\left(\mathrm{m}^{3} / \mathrm{s}\right)\end{array}$ & $\begin{array}{c}\text { Estimated by SCS } \\
\text { curve number } \\
\text { method }\left(\mathrm{m}^{3} / \mathrm{s}\right)\end{array}$ \\
\hline $\begin{array}{l}\text { 19th of } \\
\text { September, } \\
2000\end{array}$ & 179.35 & 239.44 & 204.08 & 146.52 \\
\hline
\end{tabular}

${ }^{*}$ Maximum one day rainfall $160 \mathrm{~mm}$.

TABLE 7: Comparison of study models in drainage basin with index of relative mean error (RME) and root of mean square error (RMSE).

\begin{tabular}{llc}
\hline Applied models & RME & RMSE \\
\hline Manning equation & 33.50 & 60.09 \\
Kinematic wave parameter & 13.79 & 24.73 \\
SCS curve number & 18.30 & 32.83 \\
\hline
\end{tabular}

are $88.73 \mathrm{~mm}$. Now, the runoff depth value can be used to estimate the peak runoff in cumec. After calculation the value is $146.52 \mathrm{~m}^{3} / \mathrm{s}$ (Table 5 ).

As for as the factors of models are concerned, these can be applied and able to estimate discharge amount. In this section instead of results of each model, all the predicted data has been compared with effective discharge data, taking as observed discharge to determine the level of efficiency between three models (Table 6). Error functions were calculated to determine precision of each model. Functions considered in this section are relative mean error (RME) and root of mean square error (RMSE). It is evident from the results that the kinematic wave parameter model has the minimum error among the study models with RME value of 13.79 and RMSE value of 24.73 (Table 7).

\subsection{Preparation of Monthly Hydrograph for Kunur River} during Monsoon Period. In general, hydrograph of basins is a pictorial representation of water availability with temporal change. It is treated as basic component of river basin management, for better irrigation practices, dam construction, flood damage control, recreation, and so forth. To prepare the monthly hydrograph of the Kunur River, SCS curve number method has been used for its efficiency of runoff estimation. Same methodology has been followed here for each day of the entire month September (Table 8), which was previously applied to estimate the peak discharge of the Kunur River for only the 19th of September for highest rainfall occurrence (160 mm).

This hydrograph represents the relationship between rainfall occurrences and runoff generation. In the same way, basin area has the correlation value of 0.93 during September.

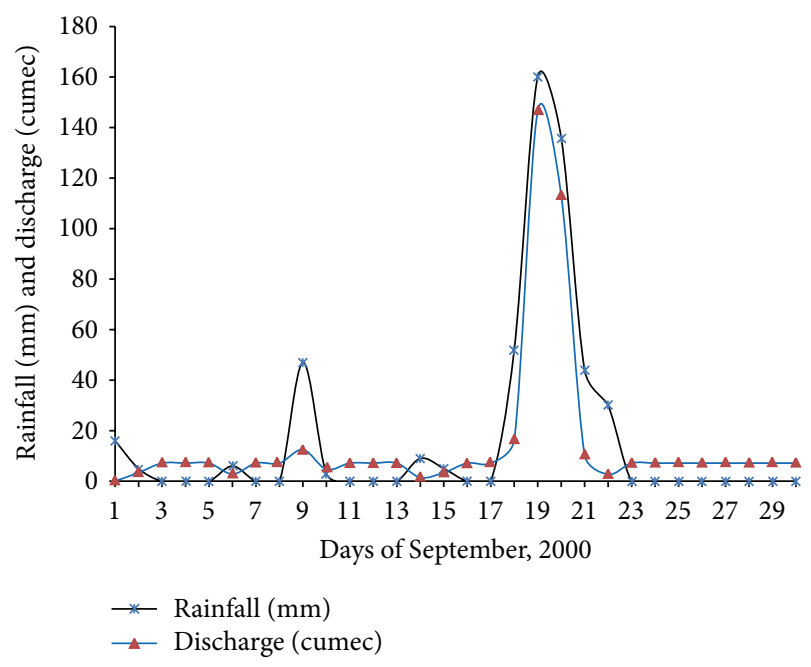

FIgURE 7: Monsoonal hydrograph (September) of Kunur River Basin.

The correlation coefficient 0.93 indicates a relatively strong relationship between the rainfall and runoff amounts for the selected episodes at the catchment scale. The polynomial $R^{2}$ statistic indicates that the model explains $99.5 \%$ of the variability in the runoff amount. The major characteristic of this hydrograph is single extreme peak period the end of September generating highest discharge $\left(146.53 \mathrm{~m}^{3} / \mathrm{s}\right)$ with direct runoff of $55.46 \%$ rainfall (Figure 7 and Table 8 ). This hydrograph peak is developed due to the sudden heavy and continuous rainfall during 18th to 22nd of September, 2000. As a result, a havoc flood condition was generated in the confluence zone of Ajay and Kunur Rivers [27, 32]. This hydrograph proved very good application for flood forecasting and management in the lower Ajay River Basin during the monsoon period as well as downstream area of Kunur Basin. As per Rudra and Mukhopadhyay [27, 32], the lower Ajay River Basin is frequently affected by havoc flood at the end of September to the mid of October month. This hydrograph also proved its comment about flood characteristic of the study area. 
TABLE 8: Monthly discharge estimation using SCS curve number method of Kunur River Basin.

\begin{tabular}{|c|c|c|c|c|c|c|c|}
\hline $\begin{array}{l}\text { Days } \\
\text { (Sep., 2000) } \\
\end{array}$ & Rainfall $^{*}(\mathrm{~mm})$ or $P$ & $S(\mathrm{~mm})$ & $Q(\mathrm{~mm})$ & $\%$ of rainfall & $T_{c}$ & $T_{p}$ & Discharge in $\mathrm{m}^{3} / \mathrm{s}\left(q_{p}\right)$ \\
\hline 1 & 16 & & 0.02 & 0.125 & & & 0.03 \\
\hline 2 & 5 & & 2.04 & 40.8 & & & 3.37 \\
\hline 3 & 0 & & 4.33 & & & & 7.15 \\
\hline 4 & 0 & & 4.33 & & & & 7.15 \\
\hline 5 & 0 & & 4.33 & & & & 7.15 \\
\hline 6 & 6 & & 1.71 & 28.5 & & & 2.82 \\
\hline 7 & 0 & & 4.33 & & & & 7.15 \\
\hline 8 & 0 & & 4.33 & & & & 7.15 \\
\hline 9 & 47 & & 7.56 & 16.09 & & & 12.48 \\
\hline 10 & 3 & & 2.84 & 94.67 & & & 4.69 \\
\hline 11 & 0 & & 4.33 & & & & 7.15 \\
\hline 12 & 0 & & 4.33 & & & & 7.15 \\
\hline 13 & 0 & & 4.33 & & & & 7.15 \\
\hline 14 & 9 & 86.71 & 0.89 & 9.89 & 165.98 & 116.18 & 1.47 \\
\hline 15 & 5 & & 2.04 & 40.8 & & & 3.37 \\
\hline 16 & 0 & & 4.33 & & & & 7.15 \\
\hline 17 & 0 & & 4.33 & & & & 7.15 \\
\hline 18 & 52 & & 9.9 & 19.04 & & & 16.35 \\
\hline 19 & 160 & & 88.73 & 55.46 & & & 146.53 \\
\hline 20 & 136 & & 68.56 & 50.41 & & & 113.22 \\
\hline 21 & 44 & & 6.27 & 14.25 & & & 10.35 \\
\hline 22 & 30 & & 1.61 & 5.37 & & & 2.66 \\
\hline 23 & 0 & & 4.33 & & & & 7.15 \\
\hline 24 & 0 & & 4.33 & & & & 7.15 \\
\hline 25 & 0 & & 4.33 & & & & 7.15 \\
\hline 26 & 0 & & 4.33 & & & & 7.15 \\
\hline 27 & 0 & & 4.33 & & & & 7.15 \\
\hline 28 & 0 & & 4.33 & & & & 7.15 \\
\hline 29 & 0 & & 4.33 & & & & 7.15 \\
\hline 30 & 0 & & 4.33 & & & & 7.15 \\
\hline
\end{tabular}

${ }^{*}$ Rainfall data computed by River Research Institute, Kolkata, in 2000.

There are several other hydrological models and methods of runoff and discharge estimation form ungauged basins. But, in this study, these three models have been applied for their geomorphic approach and worldwide acceptability for their easy and RS-GIS based application. Although there are some errors in these models, but the major objective of this study has been fulfilled. This study helps to get an approximate idea about the hydrological behavior of Kunur River during the heavy rainfall season. This research work helps to estimate the maximum channel capacity of the Kunur River Basin and may be applicable for other ungauged river basin and also helps to prepares monthly hydrograph for the selected period. The major findings of this work is that this basin has very good potentiality for water harvesting during the rainy seasons and it can reduced the flood probability of the month September by developing water bank for cultivation in the lean season. This research paper also demonstrates an approach to generate reliable discharge data for different vulnerable ungauged river basins in sense of draught prone and flood prone areas in the developing countries, particularly for India, where most of the middle and small sized watersheds have no discharge data. But these ungauged watersheds may have chance to form havoc flood event and economic losses for the surrounding settlements. Overall, these applications obviously provide the benefits for citations of hydrological information about this basin.

\section{Conclusion}

Across the globe, water resources and the water environment are under threat like never before. In this case, in river basins, everywhere, human activities have disrupted the natural 
hydrological and ecological regimes. Water supplies are not secured to billions of people worldwide. Flood risk is increasing and biodiversity is steadily decreasing due to the ongoing destruction of riparian ecosystems. At that moment, prediction of actuate amount of water resource for every small and large basins is absolutely essential for water planning. Prediction in ungauged basin (PUB) is one of the recent developmental strategies by the International Association of Hydrological Sciences (IAHS) for proper hydrological planning in basin-scale water and resource management. The channel geometry method is a simple and useful alternative method of estimating flood discharge compared with methods based upon catchment characteristics. Recently, application instream local level geomorphic study is an important and significant way for calculating hydrological behaviors of watershed with least error and cost. The study reveals that comparative study of alternative hydrological models provides flood estimates, which are adequate for the planning and design of various hydraulic structures and for flood frequency analysis.

\section{Acknowledgments}

The authors would like to thank one of their friends Ratanpriya Jaiswal, Research Scholar of CSRD-JNU, for her remarks on the paper writing and would also like to thank Sadhan Mallik and Subhankar Bera, Ex-Student of The University of Burdwan, for their contribution during data collection.

\section{References}

[1] A. K. Sing, S. Sharma, and U. Vakharia, "GIS, remote sensing and field measurement for estimating hydrological parameters in ungauged catchment," in Proceedings of the 12th Esri India User Conference, pp. 1-8, 2011.

[2] V. K. Bhatt and A. K. Tiwari, "Estimation of peak streamflows through channel geometry," Hydrological Sciences Journal, vol. 53, no. 2, pp. 401-408, 2008.

[3] S. A. Schumm, "River adjustment to altered hydro-logic regimeMurrumbidgee River and palaeochannels, Australia," US Geological Survey Professional Paper 598, 1968.

[4] J. R. Reddy, A Textbook of Hydrology, University Science Press, New Delhi, India, 2010.

[5] G. H. Dury, "Bed-width and wave-length in meandering valleys," Nature, vol. 176, no. 4470, pp. 31-32, 1955.

[6] G. H. Dury, "Discharge prediction, present and former, from channel dimensions," Journal of Hydrology, vol. 30, no. 3, pp. 219-245, 1976.

[7] K. J. Tinkler, "Active valley meanders in south-central Texas and their wider implications," Geological Society of America Bulletin, vol. 82, pp. 1783-1800, 1971.

[8] P. C. Patton and V. R. Baker, "Geomorphic response of central Texas stream channels to catastrophic rainfall and runoff," in Geomorphology in Arid Regions. Proc. 8th Binghamton Symposium in Geomorphology, 1977, D. O. Doehring, Ed., pp. 189-217, Publications in Geomorphology, SUNY, Binghamton, NY, USA, 1977.

[9] J. C. Knox, "Responses of floods to Holocene climatic change in the upper Mississippi Valley," Quaternary Research, vol. 23, no. 3, pp. 287-300, 1985.
[10] J. C. Knox, "Climatic influence on upper Mississippi Valley floods," in Flood geomorphology, V. R. Baker, R. C. Kochel, and P. C. Patton, Eds., pp. 279-300, John Wiley, New York, NY, USA, 1988.

[11] G. P. Williams, "Paleofluvial estimates from dimensions of former channels and meanders," in Flood Geomorphology, V. R. Baker, R. C. Kochel, and P. C. Patton, Eds., pp. 321-334, John Wiley, New York, NY, USA, 1988.

[12] W. B. Langbein, "Hydrologic data networks and methods of extrapolating or extending available hydrologic networks," Flood Control Series 15, United Nations Economics Commission for the Far East, Bangkok, Thailand, 1960.

[13] E. R. Hedman, P. O. Moore, and R. K. Livingstone, "Selected streamflow characteristics as related to channel geometry of perennial streams of Colorado," US Geol. Survey Open-File Report (200) H358s, 1972.

[14] E. R. Hedman and W. R. Osterkamp, "Streamflow characteristics related to channel geometry of streams in western United States," US Geological Survey Water-Supply Paper 2193, 1982.

[15] A. G. Scott and J. L. Kunkler, "Flood discharges of streams in New Mexico as related to channel geometry," US Geol. Survey Open File Report 76-414, Washington DC, USA, 1976.

[16] H. C. Riggs, "Streamflow characteristics from channel size," Journal of the Hydraulics Division, vol. 104, no. 1978, pp. 87-96, 1978.

[17] W. R. Osterkamp and E. R. Hedman, "Discharge estimates in surface mine areas using channel geometry techniques," in Proceedings of Symposium on Surface Mining Hydrology, Sedimentology and Reclamation, University of Kentucky, Lexington, Ky, USA, 1979.

[18] E. E. Webber and J. W. Roberts, "Flood flow characteristics related to channel geometry in Ohio," US Geol. Survey Open File Report 81-1105, Washington, DC, USA, 1981.

[19] R. J. Omang, C. Parrett, and J. A. Hull, "Mean annual runoff and peak flow estimates based on channel geometry of streams in southeastern Montana," US Geol. Survey Water Resource Investigations Report 82-4092, Washington, DC, USA, 1983.

[20] K. L. Wahl, "Determining streamflow characteristics based on channel cross section properties," in Improving Estimates from Flood Studies, Transportation Research Record no. 922, pp. 1-10, Transportation Research Board, Washington, DC, USA, 1983.

[21] K. L. Wahl, "Evolution of the use of channel cross section characteristics for estimating streamflow characteristics," US Geol. Survey Water Supply Paper 2262, Washington, DC, USA, 1984.

[22] S. M. Lawlor, "Determination of channel-morphology characteristics, bankfull discharge, and various design-peak discharges in western Montana," Scientific Investigations Report 20045263, US Geol. Survey, Reston, Va, USA, 2004.

[23] G. P. Williams, "Bankfull discharge of rivers," Water Resource Research, vol. 14, no. 6, pp. 1141-1154, 1978.

[24] A. Sridhar, "Discharge estimation from planform characters of the Shedhi River, Gujarat alluvial plain: present and past," Journal of Earth System Science, vol. 116, no. 4, pp. 341-346, 2007.

[25] V. S. Kale, V. U. Joshi, and P. S. Hire, "Palaeohydrological reconstructions based on analysis of a Palaeochannel and Toba-Ash Associated alluvial sediments in the Deccan Trap region, India," Journal of the Geological Society of India, vol. 64, no. 4, pp. 481489, 2004.

[26] S. C. Mukhopadhyay and A. Dasgupta, River Dynamics of West Bengal (Vol. II) Applied Aspect, Prayas Publishers, Kolkata, India, 2010. 
[27] K. Rudra, "Banglar Nadikatha," (in Bengali), Sahitya Samsad, Kolkata, pp. 11-19, 58-69, and 78-92, 2008.

[28] S. Mukherjee, "Floods in West Bengal," in Geographical MosaicProfessor K.G. Bagechi Felicitation, S. P. Chatterjee, Ed., pp. 263270, Manasi Press, Calcutta, India, 1985.

[29] P. K. Sen, "The genesis of floods in the lower Damodar catchment," in The Concept and Methods in Geography, P. K. Sen, Ed., pp. 71-85, The University of Burdwan, Burdwan, India, 1985.

[30] S. Roy, "Spatial variation of floods in the lower Ajay River Basin, West Bengal: a geo-hydrological analysis," International Journal of Remote Sensing and GIS, vol. 1, no. 2, pp. 132-143, 2012.

[31] B. Mitra, "Expediency of surrogate data in accounting hydrological balance of small River Basin: a case study of the Kunur Basin," Indian Journal of Landscape System and Ecological Studies, vol. 25, no. 1, pp. 38-48, 2002.

[32] S. Mukhopadhyay, "A geo-environmental assessment of flood dynamics in lower Ajoy River including Sand Splay problem in Eastern India," Ethiopian Journal of Environmental Studies and Management, vol. 3, no. 2, pp. 99-110, 2010.

[33] V. T. Chow, Handbook of Applied Hydrology, McGraw-Hill, New York, NY, USA, 1964.

[34] S. Ghosh and S. Ghosh, "Land degradation due to indiscriminate "Murrum" extraction near Durgapur Town, West Bengal," in Land Degradation and Desertification, V. C. Jha, Ed., pp. 257258, Rawat Publication, New Delhi, India, 2003.

[35] M. Niyogi, "Ground water resource of the Ajay Basin," in Geographical Mosaic- Professor K.G. Bagechi Felicitation, S. P. Chatterjee, Ed., pp. 165-182, Manasi Press, Calcutta, India, 1985.

[36] H. H. Barnes Jr., "Roughness characteristic of natural channels," U.S. Geological Survey Water-Supply Paper 1849, 1967.

[37] M. A. Benson and T. Dalrymple, "General field and office procedures for indirect discharge measurements," U.S. Geological Survey, Techniques of Water-Resources Investigations, Book 3, Chapter A-1, 1967.

[38] J. T. Limerinos, "Determination of the manning coefficient from measured bed roughness in natural channels," U.S. Geological Survey Water-Supply Paper 1898-B, 1970.

[39] R. D. Jarrett, "Determination of roughness coefficients for streams in Colorado," U.S. Geological Survey Water Resources Investigations Report 85-400, 1985.

[40] M. A. Summerfield, Global Geomorphology: An Introduction to the Study of Landform, Pearson Education, Edinburgh, UK, 1st edition, 1991.

[41] H. H. Bengtson, "Uniform open channel flow and manning equation (Course 501)," Morrisville, pp. 1-26, 2011, http://www .pdhsite.com.

[42] A. D. Knighton, "Fluvial forms and processes," Edward Arnold, Sheffield, North America, Chapter 4, 1984.

[43] R. Manning, "On the flow of water in open channels and pipes," Transactions of the Institution of Civil Engineers of Ireland, vol. 20, pp. 161-207, 1891.

[44] A. L. Bloom, Geomorphology, a Systematic Analysis of Late Cenozoic Landforms, PHI Learning Private, New Delhi, India, 3rd edition, 2009.

[45] D. B. Simons and E. V. Richardson, "Forms of bed roughness in alluvial channels," Transactions of the American Society of Civil Engineers, vol. 128, p. 289, 1963.

[46] G. J. Arcement Jr. and V. R. Schneider, "Guide for selecting Manning's roughness coefficients for natural channels and flood plains," US Geological Survey Water-Supply Paper 2339, 1989.
[47] V. T. Chow, Open-Channel Hydraulics, McGraw-Hill, New York, NY, USA, 1959.

[48] B. C. Yen, "Open channel flow resistance," Journal of Hydraulic Engineering, vol. 128, no. 1, pp. 20-39, 2002.

[49] A. Mohammadi, H. Ahmadi, E. Taghvaye Salimi, Sh. Khalighi, and A. Sallajegheh, "Regional model presentation for peak discharge estimation in ungauged drainage basin using geomorphologic, Synyder, SCS and triangular models (case study: Kan drainage basin)," Caspian Journal of Environmental Sciences, vol. 10, no. 1, pp. 91-102, 2012.

[50] I. Rodriguez-Iturbe, G. Devoto, and J. B. Valdes, "Discharge response analysis and hydrologic similarity: the interrelation between the geomorphologic IUH and the storm characteristics," Water Resources Research, vol. 15, no. 6, pp. 1435-1444, 1979.

[51] Soil Conservation Service, "National engineering handbook," Section 4, Hydrology, Department of Agriculture, Washington, p. 450,1964 .

[52] Soil Conservation Service, "National engineering handbook," Section 4, Hydrology, Department of Agriculture, Washington, p. $762,1972$.

[53] Z. P. Kirpich, "Time of concentration of small agricultural watersheds," Civil Engineering, vol. 6, p. 362, 1940. 

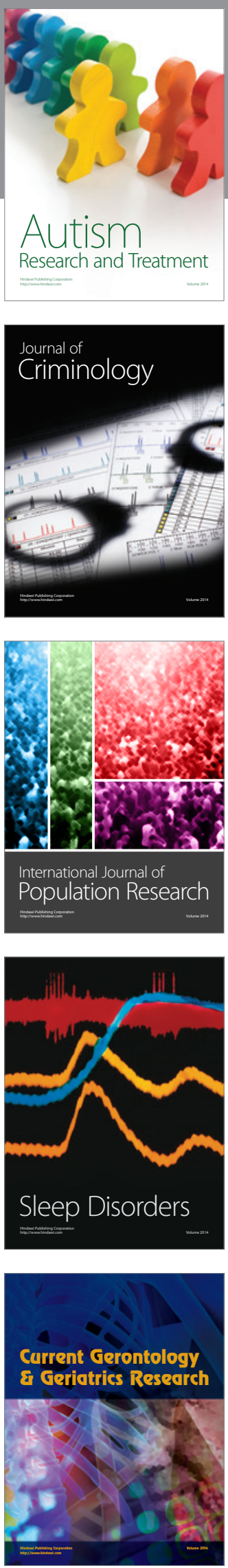
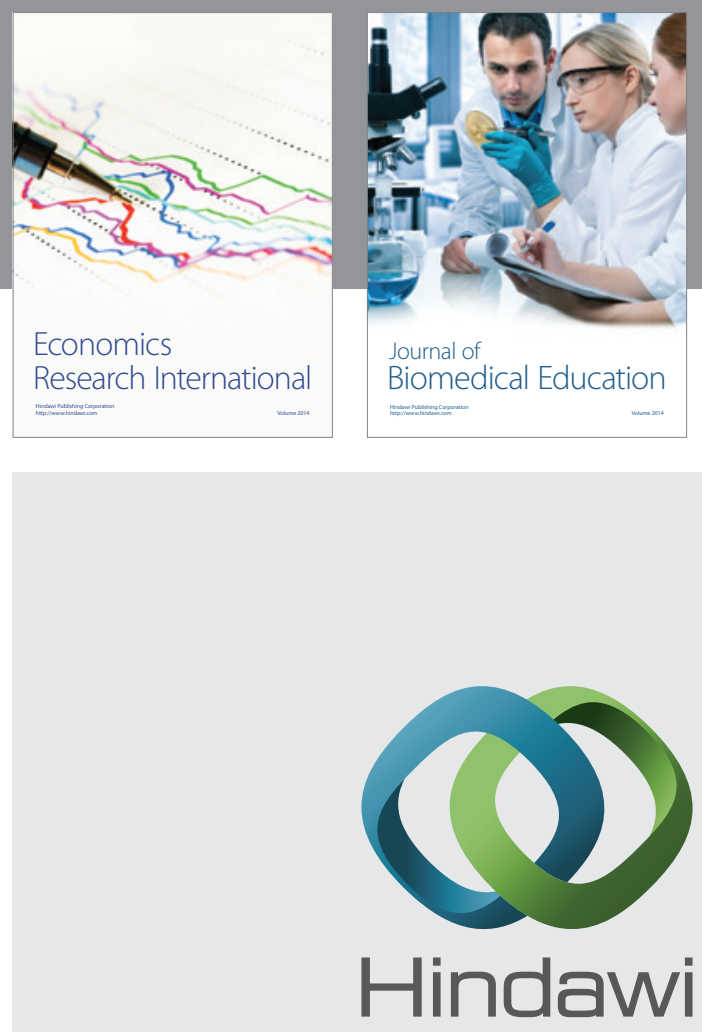

Submit your manuscripts at

http://www.hindawi.com
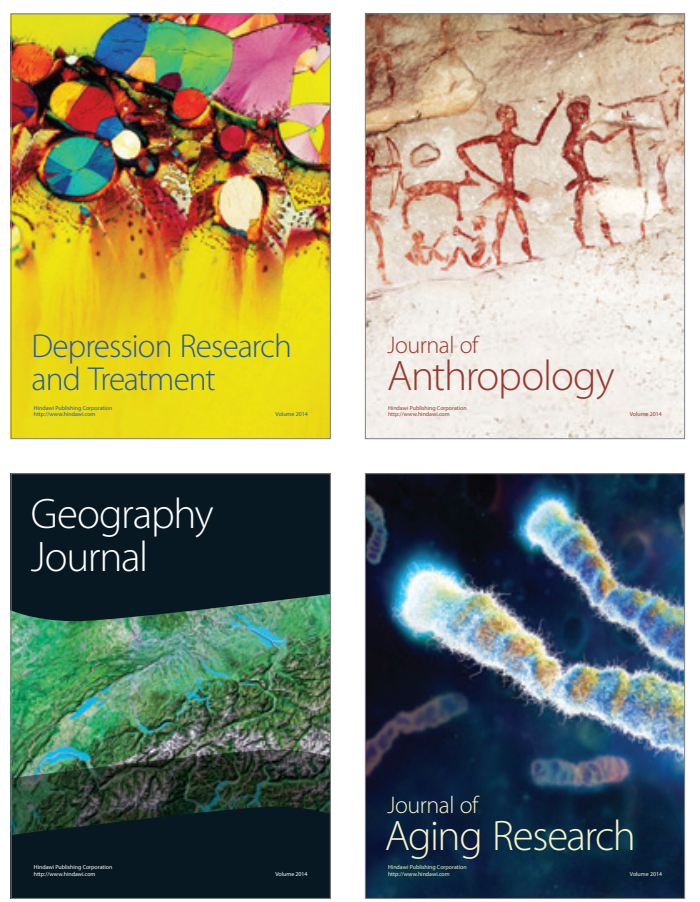
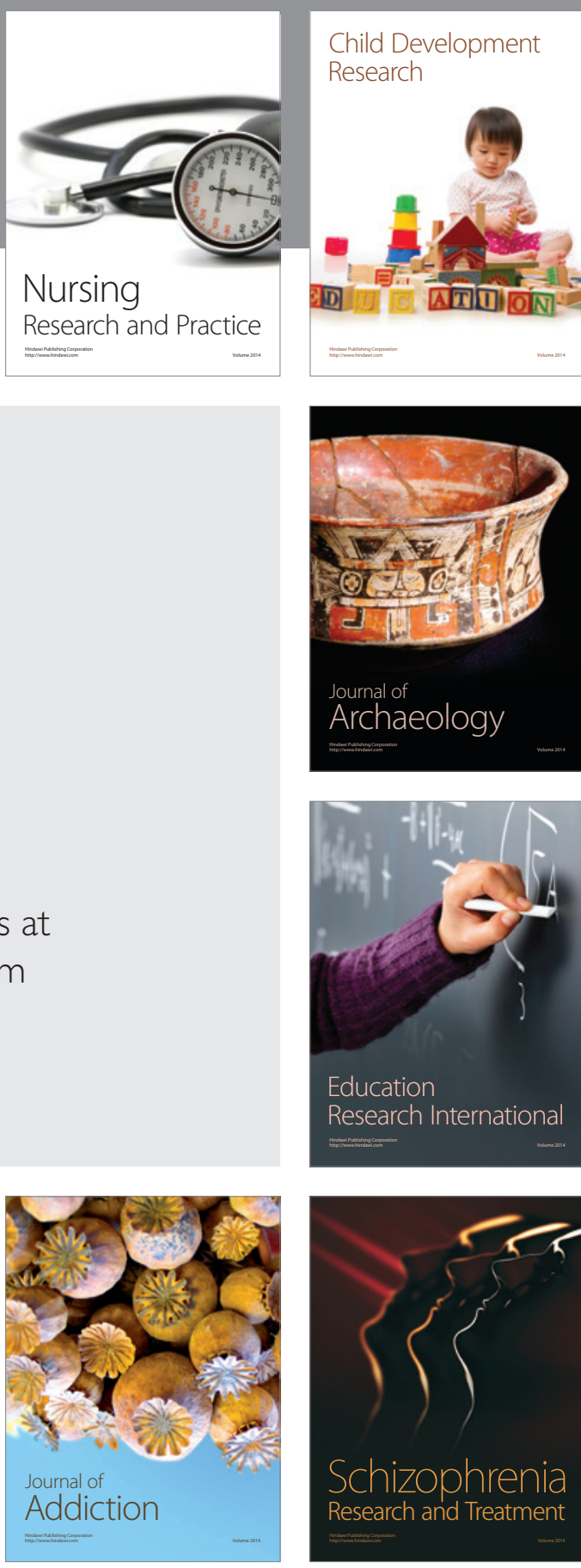

(D)
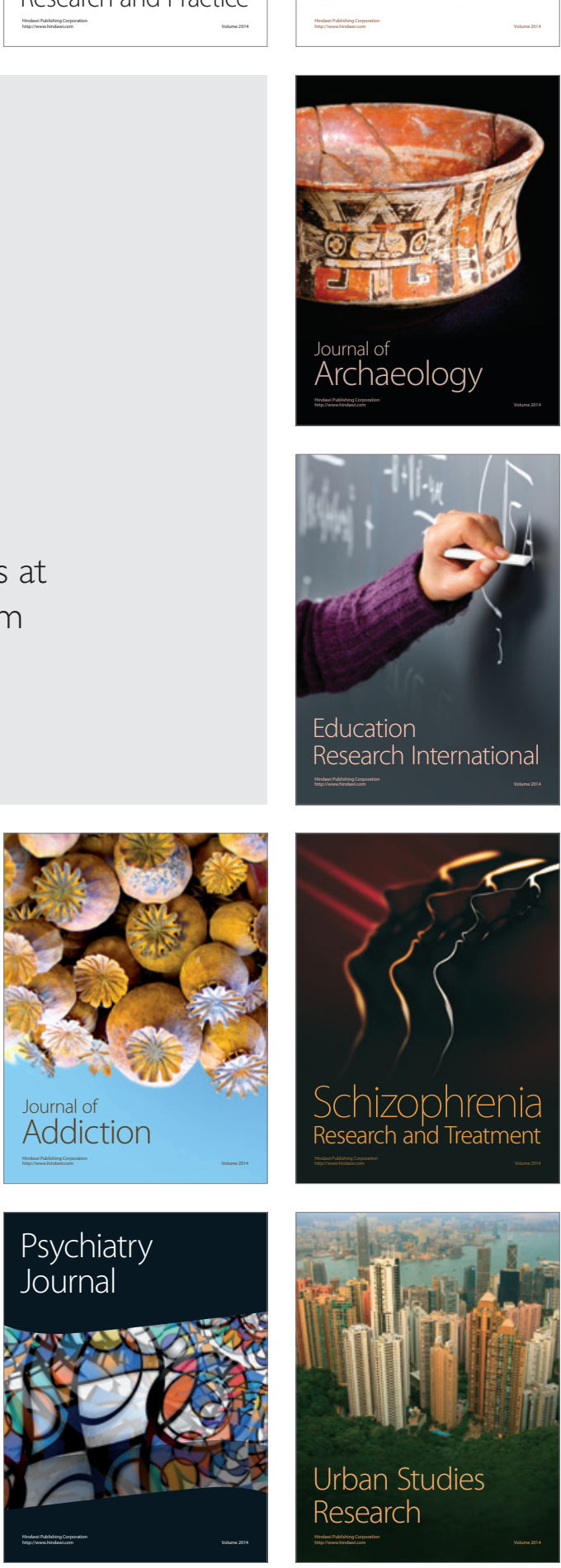